\title{
ANALISIS PERMASALAHAN PEREMPUAN DAN POTENSI LOKAL DI KABUPATEN GUNUNGKIDUL DAERAH ISTIMEWA YOGYAKARTA
}

\author{
Sujarwo dan Lutfi Wibawa \\ Universitas Negeri Yogyakarta \\ email: sujarwo@uny.ac.id
}

\begin{abstract}
ABSTRAK: Analisis Permasalahan Perempuan dan Potensi Lokal di Kabupaten Gunungkidul Daerah Istimewa Yogyakarta. Penelitian ini bertujuan untuk memperoleh informasi tentang masalah yang dihadapi oleh perempuan khusunya ibu rumah tangga yang tidak memiliki pekerjaan tidak tetap dan memperoleh gambaran tentang potensi lokal yang dapat dikembangkan untuk pemberdayaan perempuan di Desa Bejiharjo Kecamatan Karangmojo Kabupaten Gunungkidul Daerah Istimewa Yogyakarta. Penelitian ini menggunakan pendekatan deskriptif kualitatif dengan sasaran kelompok-kelompok perempuan di Desa Bejiharjo. Data penelitian dikumpulkan dengan teknikfocus group discussion, wawancara mendalam, dokumentasi, dan observasi. Data yang terkumpul dianalisis dengan teknik analisis deskriptif kualitatif. Hasil penelitian menunjukan bahwa: 1) permasalahan yang dihadapi oleh perempuan khususnya ibu rumah tangga yang tidak memiliki pekerjaan tidak tetap dapat dikelompokan: a) permasalahan yang berkaitan dengan kemiskinan, b) sosial budaya, c) kekerasan rumah tangga, d) pendidikan dan latihan, e) adat istiadat, dan f) akses sosial perempuan sangat terbatas; 2) banyak potensi yang dapat dimanfaatkan untuk memberdayakan perempuan terutama ibu-ibu rumah tangga yang tidak bekerja di Bejiharjo, antara lain: a) optimalisasi pemanfaatan sumber daya alam, b) sumber daya manusia, c) karakter budaya, dan d) jejaring sosial dan modal sosial yang sangat potensial untuk dikembangkan.
\end{abstract}

Kata Kunci: Analisis Permasalahan Perempuan, Potensi Lokal, dan Gunungkidul.

\begin{abstract}
Analysis on Women's Issues and Local Potency in The Gunungkidul District of Yogyakarta. This research is aimed to obtain information about the problems faced by women especially housewives who have no fixed job, and get a picture of the local potential that can be developed for the empowerment of women in the village Bejiharjo Karangmojo Gunungkidul District of Yogyakarta Special Region. This study used a qualitative descriptive approach targeting women's groups in the village Bejiharjo. Data were collected by focus group discussion techniques, in-depth interviews, documentation and observation. The data were analyzed with descriptive qualitative analysis techniques. The results showed that: 1) the problems faced by women, especially housewives who have no fixed jobs can be categorized as: a) problems associated with poverty, b) socio-cultural, c) domestic violence, d) education and training, e) customs, and f) women's very limited access to social; 2) a lot of potential that can be harnessed to empower women, especially housewives who do not work in Bejiharjo, include: a) optimizing the utilization of natural resources, b) human resources, c) cultural character, and d) social networking and social capital, which is very potential to be developed.
\end{abstract}

Keywords: Analysis of Women's Issues, Local Potential, and Gunungkidul.

\section{PENDAHULUAN}

Kasus kekerasan dalam rumah tangga terhadap perempuan di Kabupaten Gunung
Kidul, Daerah Istimewa Yogyakarta naik sekitar 75 persen pada 2010 dibandingkan pada 2009, dari 27 kasus menjadi 41 kasus. 
Kasus kekerasan yang menimpa perempuan dalam rumah tangga terjadi dalam bentuk kekerasan fisik, sosial dan ekonomi yang menjadikan posisi perempuan dan anak kurang berdaya sehingga sering menjadi objek kekerasan dari anggota keluarga yang lebih berkuasa.

Salah satu tujuan pembangunan di Indonesia untuk mewujudkan masyarakat yang adil, makmur dan sejahtera tanpa membedakan laki-laki atau perempuan. Meskipun telah banyak kemajuan pembangunan yang dicapai, namun kenyataan menunjukkan bahwa kesenjangan gender (gender gap) masih terjadi pada sebagian besar bidang pembangunan, terutama bidang pendidikan, kesehatan, dan ekonomi. Isu kesenjangan gender inilah yang membatasi keterlibatan kaum perempuan dalam pembangunan dan berdampak terhadap pencapaian kualitas hidupnya.

Apabila dibandingkan dengan Negaranegara ASEAN yang lain, Indeks Pembangunan Gender Negara Indonesia berada pada peringkat ke-81 dari 136 negara dan Indeks Pemberdayaan Gender adalah 58,9\% hampir sejajar dengan Negara-negara Laos, Kamboja, dan Myanmar (Kementerian Negara Pemberdayaan Perempuan RI dalam Dwi Darmanto. 2010). Untuk mengejar ketertinggalan itu maka pembangunan Indonesia harus dilakukan dalam perspektif pembangunan berwawasan gender yang menjadikan perempuan dan laki-laki sebagai anggota masyarakat mempunyai kedudukan dan hak yang sama atas akses, manfaat, partisipasi, dan kontrol dalam pembangunan.

Teori human capital menjelaskan bahwa investasi human capital (modal dasar seperti pendidikan, penghasilan) memberi investasi bagi seseorang untuk dapat lebih berkuasa. Hasil penelitian Buur, dkk. (1977) mengungkapkan sumber daya perempuan besar peranannya pada relasi kekuasaan suami isteri dalam keluarga. Isteri yang bekerja dan berpenghasilan cenderung mempunyai peluang yang lebih besar dalam pengambilan keputusan di keluarganya dibanding dengan istri yang tidak bekerja atau tidak berpenghasilan (Farida Hanum, 2010). Pada aspek keterampilan, sebagian besar perempuan khususnya yang berperan sebagai ibu rumah yang tidak bekerja atau tidak berpenghasilan Desa Bejiharjo tidak memiliki keterampilan yang berarti untuk mencari nafkah. Sebagian besar perempuan kadang-kadang bekerja mengerjakan lahannya sendiri atau buruh tani di tempat orang lain. Para perempuan yang memiliki keterampilan, ternyata juga merasa bahwa keterampilan yang telah dimiliki masih belum cukup untuk dapat digunakan sebagai modal berusaha. Beberapa keterampilan yang pernah mereka terima antara lain: pembuatan keripik singkong dan membuat selai pisang. Keterampilan yang telah diperoleh juga belum banyak dipraktikkan, ada sebagian dari mereka yang pernah memraktikkannya, tetapi lebih banyak untuk kebutuhan sendiri, tidak untuk dijual, padahal keterampilan yang diinginkan adalah keterampilan berusaha/berjualan.

Dalam berhubungan sosial, masyarakat Desa Bejiharjo Kecamatan Semanu Kabupaten Gunungkidul pada umumnya menganut paham patrilineal yang menyebabkan laki-laki memiliki dominasi yang sangat kuat. Laki-laki lebih berperan dalam hubungan antara keluarga dengan kelembagaan masyarakat, sehingga sangat melemahkan peran dan aktivitas perempuan pada organisasi masyarakat. Perempuan adalah masyarakat "kelas dua" yang sering kali tidak dapat memperoleh hak-haknya sebagaimana mestinya. Para ibu rumah tangga di daerah ini, lebih banyak mengurus rumah, tanah pekarangan, sawah, dan anak-anak di rumah, kalaupun ada sebagian ibu rumah tangga yang bekerja, sifatnya hanya membantu suaminya mengurus lahannya sendiri atau ikut gotong royong membantu pengerjaan lahan tetangga. Di samping itu, sebagian besar perempuan ibu rumah tangga tersebut bekerja di sektor informal dan buruh tani.

Masyarakat Desa Bejiharjo Kecamatan Karangmojo masih sangat kental dengan tradisi atau adat istiadat yang berlaku di desa 
ini seperti upacara-upacara adat, misalnya rasulan, "resik desa", upacara kematian (tiga hari, tujuh hari, empat puluh hari, seratus hari, seribu hari, dan sebagainya). Peran isteri dalam keluarga adalah mengasuh anak-anak, menjaga rumah dan harta yang dimiliki, serta membantu pekerjaan suami, sehingga yang bertanggung jawab penuh mencarai nafkah adalah suami. Masyarakat di daerah ini, khusunya ibu-ibu rumah tangga, rata-rata memiliki keterampilan yang masih rendah, terutama yang berkaitan dengan pengolahan sumber daya alam yang ada. Mereka belum memiliki keterampilan yang baik, sehingga perlu dilakukan pelatihan keterampilan dan kecakapan terhadap pemanfaatan sumber daya yang ada guna meningkatkan keterampilan-keterampilan mereka dalam hal usaha ekonomi produktif.

Desa Bejiharjo Kecamatan Karangmojo merupakan salah satu desa yang memiliki potensi wisata "Gua Pindul” yang mulai dikenal oleh wisatawan lokal dan internasional, sehingga perempuan dapat diberdayakan sesuai dengan potensi daerah yang dimiliki. Selain itu, upaya optimalisasi kelompok belajar (keaksaraan fungsional dan aksara kewirausahaan), serta organisasi ekonomi di desa tersebut perlu diberdayakan untuk mendukung peningkatan pendapatan masyarakat, khususnya perempuan ibu rumah tangga.

Melihat kondisi tersebut maka perlu dilakukan penelitian yang bersifat eksploratif dan deskriptif sebagai upaya menemukan informasi mengenai permasalahan dan potensi dalam upaya pemberdayaan perempuan khususunya ibu rumah tangga yang tidak memiliki pekerjaan tetap di Desa Bejiharjo Kecamatan Karangmojo Kabupaten Gunungkidul sehingga perempuan mampu mengembangkan dirinya menjadi perempuan yang berdaya.

\section{METODE}

Penelitian ini menggunakan pendekatan deskriptif kualitatif. Penelitian ini dilaksana-kan di Desa Bejiharjo Kecamatan Karangmojo dengan sasaran kelompok-kelompok perempuan.

Data primer yang dikumpulkan meliputi; 1) karakter budaya lokal termasuk nilai dan norma yang berlaku dalam masyarakat, 2) sumber daya lokal (manusia dan alamnya), 3) kelembagaan (struktur sosial dan ekonomi), 4) jejaring dan perilaku masyarakat, 5) aset dan akses masyarakat, dan 6) sumber dana. Secara khusus kondisi perempuan khususnya ibu rumah tangga yang tidak bekerja difokuskan pada permasalahan yang berkaitan dengan: 1) perempuan dan kemiskinan, 2) Perempuan dan kesehatan, 3) pendidikan dan pelatihan, 4) kekerasan terhadap

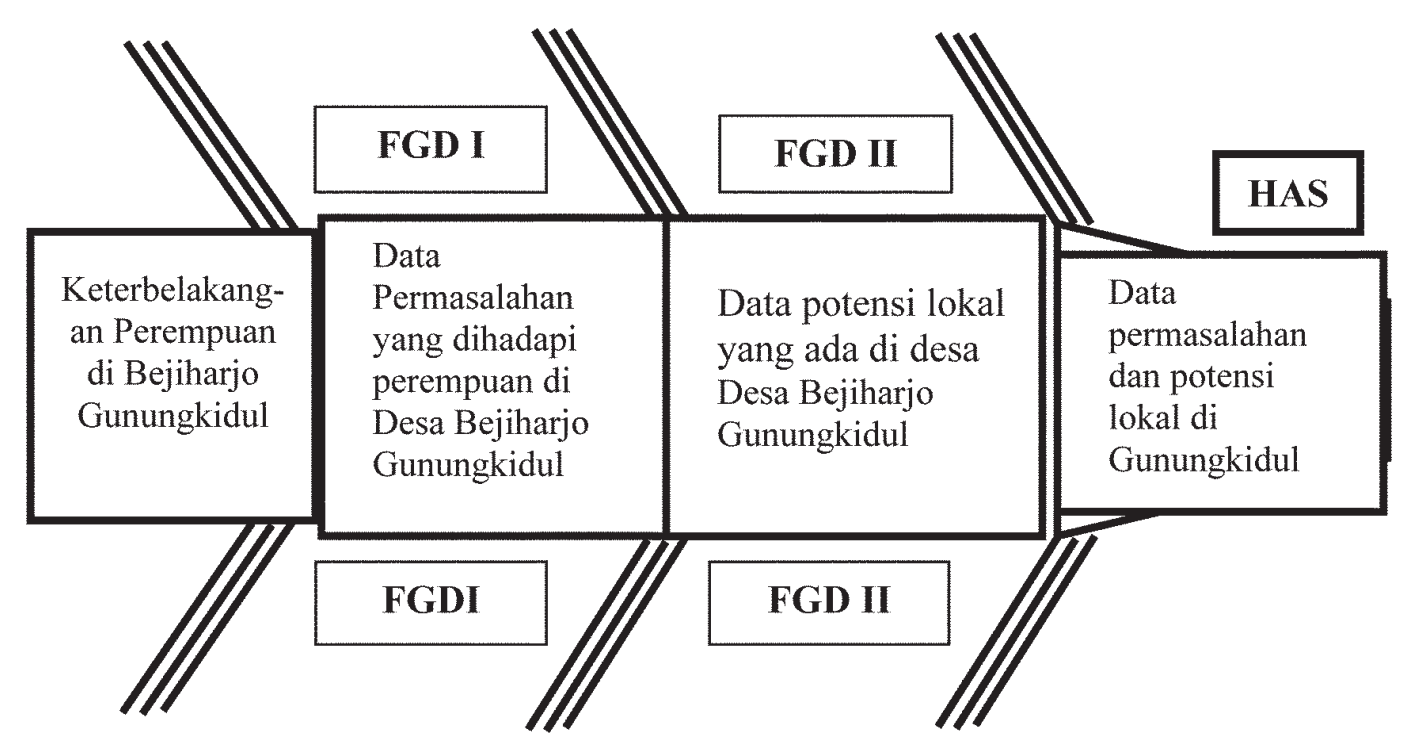

Gambar 1. Bagan Alir Proses Penelitian 
perempuan, 5) perempuan dan ekonomi, dan 6) perempuan dengan kepercayaan (budaya). Adapun data sekundernya adalah kondisi sumber daya manusia dan alam yang dimiliki, aset dan akses masyarakat desa yang digali dari dokumen laporan tahunan dari desa. Data dikumpulkan dengan menggunakan metode focus group discussion (FGD), wawancara mendalam, dokumentasi, dan observasi. Tahapan pengumpulan data dapat disajikan melalui Gambar 1.

Data yang terkumpul kemudian dianalisis dengan teknik analisis deskriptif kualitatif.

\section{HASIL DAN PEMBAHASAN}

1. Permasalahan yang Dihadapi Perempuan Khususnya Ibu Rumah Tangga yang Tidak Bekerja.

Berdasarkan data yang terkumpul ditemukan permasalahan yang dihadapi oleh perempuan khususnya ibu rumah tangga yang tidak bekerja yang dapat dikelompokan sebagai berikut.

\section{a. Permasalahan yang berkaitan dengan kemiskinan}

Kemiskinan memiliki dampak yang besar terhadap peran perempuan dalam kehidupan rumah tangga dan masyarakat. Dalam kondisi miskin, perempuan menanggung beban yang sangat berat dalam menjalankan perannya dalam keluarga dan kehidupan bermasyarakat. Ibu rumah tangga pada keluarga miskin, kurang memiliki akses dan kesempatan untuk mengembangkan diri dan memberdayakan dirinya dalam mencukupi kebutuhan dirinya sendiri dan keluarganya. Secara ekonomis, perempuan khususnya ibu rumah tangga yang tidak bekerja sangat bergantung pada suami, sanak keluarga, dan tetangganya. Ada sebagian ibu rumah tangga ini ikut membantu suami mencari nafkah untuk mencukupi kebutuhan keluarganya dengan cara menjadi buruh tani (menanam, merawat tanaman, memanen, merawat hasil panenan) atau mencari kayu bakar.

\section{b. Permasalahan yang berkaitan dengan hubungan sosial budaya}

Dalam hubungan sosial, masyarakat Desa Bejiharjo Kecamatan Karangmojo Kabupaten Gunungkidul pada umumnya menganut paham patrilineal yang menyebabkan laki-laki memiliki dominasi yang sangat kuat. Laki-laki lebih berperan dalam hubungan antara keluarga dengan kelembagaan masyarakat, sehingga sangat melemahkan peran dan aktivitas perempuan pada organisasi masyarakat. Perempuan khususnya ibu rumah tangga di Desa Bejiharjo adalah masyarakat "kelas dua" yang seringkali kurang memperoleh hak-haknya sebagaimana mestinya. Kondisi perempuan ibu rumah tangga di daerah ini, lebih banyak mengurus rumah, tanah pekarangan, sawah dan anak-anak di rumah. Kalaupun ada sebagian perempuan ibu rumah tangga yang bekerja sifatnya hanya membantu suaminya mengurus lahannya sendiri atau ikut gotong royong membantu pengerjaan lahan tetangga. Di samping itu, sebagian besar perempuan ibu rumah tangga bekerja di sektor informal dan buruh tani. Kondisi ini berlanjut secara turun temurun, sehingga hak-hak untuk mengembangkan diri dan kesempatan ibu rumah tangga masih sangat dibatasi oleh budaya dan lingkungan sosialnya.

c. Permasalahan yang berkaitan dengan kekerasan dalam rumah tangga

Meningkatnya pemahaman masyarakat terhadap kekerasan perempuan terutama dalam rumah tangga menimbulkan prevalensi angka kekerasan yang terjadi dalam keluarga. Kekerasan terhadap perempuan dalam keluarga memberikan dampak yang sangat besar terhadap kehidupan anggota keluarga, khususnya kualitas hidup perempuan dan anakanaknya. Bentuk kekerasan yang dialami perempuan khususnya ibu rumah tangga yang tidak bekerja meliputi: 1) kekerasan fisik (ditampar, dilukai, dipukul, atau ditendang), 2) kekerasan psikis (dire- 
mehkan, kadang tidak dipedulikan oleh suami, suami pergi tidak jelas, suami sering marah-marah, suami banyak menuntut tetapi kewajibannya tidak dipenuhi, suami tidak jujur, atau tidak dipedulikan oleh anggota masyarakat yang lain), 3) kekerasan sosial (dikucilkan, tidak bisa berperan dalam masyarakat secara utuh, atau tidak bisa terlibat dalam kemasyarakatan), 4) kekerasan ekonomi (sangat bergantung pada suami, sanak saudara, tetangga, dan alam sekitarnya).

d. Permasalahan yang berkaitan dengan pendidikan dan latihan

Perempuan masih menanggung beban berat diskriminasi dalam memperoleh akses pendidikan dan latihan. Kesempatan dan partisipasi perempuan, khususnya ibu rumah tangga yang tidak bekerja, di Desa Bejiharjo dalam mengikuti pendidikan dan pelatihan belum merata dan seimbang. Ibu rumah tangga yang tidak bekerja memperoleh pelatihan berkisar pada keterampilan praktis yang sifatnya konsumtif dalam pemenuhan kebutuhannya sehari-hari, seperti membuat kripik singkong, kripik pisang, dan pengelolaan sampah untuk pupuk, dan belum diarahkan pada tataran keterampilan membuka peluang usaha. Pada aspek keterampilan, sebagian besar perempuan khususnya ibu rumah yang tidak bekerja atau tidak berpenghasilan di Desa Bejiharjo tidak memiliki keterampilan yang berarti untuk mencari nafkah. Sebagian besar ibu rumah tangga kadang-kadang bekerja dengan mengerjakan lahannya sendiri atau buruh tani di tempat orang lain. Ibu-ibu yang memiliki keterampilan, ternyata juga merasa masih belum cukup untuk dapat digunakan sebagai modal usaha. Keterampil-an yang pernah diperoleh meliputi: keterampilan memasak, keterampilan membuat kripik singkong, selai pisang, dan emping mlinjo. Keterampilan yang diperoleh belum dipraktikkan secara optimal untuk meningkatkan penda- patan. Sebagian besar mereka tidak mau menerapkan keterampilan sebagai bekal untuk meningkatkan pendapat keluarga, bahkan lambat laun keterampilan tersebut telah dilupakan. Sebagian besar memilih bekerja sebagai buruh atau mencari kayu bakar yang segera mendapat hasil, tidak perlu resiko dan berpikir yang lebih rumit. Pendidikan dan keterampilan yang diperoleh kurang memberikan dampak yang berarti dalam kehidupan perempuan khususnya ibu rumah tangga selanjutnya.

e. Permasalahan yang berkaitan dengan Lingkungan hidup

Permasalahan perempuan khususnya ibu rumah tangga di Desa Bejiharjo yang terkait dengan lingkungan ditunjukan dengan kepedulian dan partisipasinya dalam mengelola dan memanfaatkan lingkungan untuk menyangga kehidupannya. Kepedulian dan partisipasi ibu-ibu rumah tangga di Desa Bejiharjo cukup baik, namun masih bersifat tradisional. Hal ini ditunjukkan dengan masih banyaknya lahan pekarangan yang kosong dan belum ditanami tanaman produktif, tetapi masih berupa tanaman konsumtif (ketela pohon, ubi jalar, beberapa pohon kayu). Tanaman ini pun masih bersifat musiman, yakni kalau musim penghujan ditanami, kalau musim kemarau dibiarkan. Lingkungan alam sekitar belum diberdayakan sebagai media dalam meningkatkan taraf hidupnya dan menjaga pelestarian lingkungan.

f. Permasalahan yang berkaitan dengan adat istiadat dan buadaya

Masyarakat Desa Bejiharjo Kecamatan Karangmojo masih sangat kental dengan tradisi atau adat istiadat yang berlaku di desa ini. Pada upacara-upacara adat tertentu, masyarakat mempersiapkan acara-acara yang sangat meriah dan menghabiskan biaya yang sangat besar. Upacara-upacara adat itu misalnya rasulan, "resik desa", dan upacara kematian (tiga hari, tujuh hari, empat puluh hari, 
seratus hari, seribu hari, dan sebagainya). Peran isteri dalam keluarga adalah mengasuh anak-anak, menjaga rumah dan harta yang dimiliki, membantu pekerjaan suami, sehingga yang bertanggung jawab penuh mencarai nafkah adalah suami, Keyakinan ini masih sangat kuat tertanam dalam hati ibu-ibu rumah tangga yang tidak bekerja.

\section{Potensi Lokal yang Dapat di Kembang- kan untuk Pemberdayaan Perempuan Khususnya Ibu Rumah Tangga yang Tidak Memiliki Pekerjaan Tetap}

Desa Bejiharjo memiliki sumber daya lokal yang sangat potensial untuk dikembangkan dalam upaya meningkatkan pendapat dan kesejahteraan anggota masyarakatnya. Secara geografis Desa Bejiharjo memiliki lahan tegalan, perbukitan, pekarangan dan sawah yang cukup luas. Lahan tersebut di dalamnya mengandung berbagai potensi yang dapat diolah dan dikembangkan menjadi potensi ekonomi yang mampu meningkatkan pendapatan masyarakat, potensi budaya yang dapat dikelola menjadi objek wisata, dan sebagai modal sosial dalam memperluas jejaring sosial dengan anggota masyarakat di luar Bejiharjo. Sumber daya lokal tersebut meliputi seni budaya, sumber daya alam, dan sumber daya manusia.

\section{a. Seni Budaya}

Ada beberapa seni budaya lokal yang berkembang dan terpelihara di Desa Bejiharjo, di antaranya adalah seperti berikut.

1) Kebersamaan dan kegotongroyongan Masyarakat Desa Bejiharjo memiliki sistem nilai dan norma yang dijunjung tinggi oleh anggota masyarakatnya. Sistem nilai yang dapat dikembangkan untuk memberdayakan perempuan antara lain: kebersamaan dan kegotong- royongan masyarakat desa yang masih kuat, kebiasaan anggota masyarakat yang masih menjunjung tinggi nilai sopan santun, "unggah ungguh", saling percaya dan cenderung masih berkomunikasi secara langsung. Beberapa potensi tersebut dapat digali dan dimanfaatkan untuk memberdayakan perempuan dalam meningkatkan taraf hidup dan kesejahteraan melalui usaha bersama (misalnya KUM, Koperasi, KBU,). Sebagian mereka dapat mengelola keunggulan budaya menjadi wisata budaya atau wisata religi. Sebagian potensi ini telah dimanfaatkan oleh ibu-ibu di Desa Bejiharjo yang tergabung dalam seni tradisional karawitan Omah Pasinaon yang setiap hari Sabtu mengisi kegiatan seninya di Wisata Gua Pindul.

2) Monumen Jendral Soedirman

Di desa ini pula terdapat monumen yang menjadi penanda sejarah peristiwa pengeboman Belanda atas Desa Bejiharjo. Pengeboman tersebut dilakukan karena dusun Gelaran II Desa Bejiharjo merupakan Markas Komando Pemerintahan Militer Kabupaten Gunungkidul. Pada tanggal 10 Maret 1949 dusun tersebut diserbu dan dibumihanguskan. Monumen ini dapat dimanfaatkan sebagai salah satu wisata sejarah untuk memperkuat wisata goa, sehingga akan memperluas lapangan pekerjaan dan menambah pendapatan masyarakat.

3) Gejoh Lesung/Alat Musik Tradisional

Gejoh lesung adalah salah satu seni tradisional dari Yogyakarta. Seni yang merupakan bentuk ucapan syukur kepada Dewi Sri atau Dewi Padi atas melimpahnya panen padi itu terancam punah. Dulu, lesung dipakai untuk memisahkan padi dari batangnya. Perkembangan zaman memang memudahkan manusia untuk mengolah padi dengan cepat. Menumbuk di dalam lesung sudah dinilai kurang efektif.

Gejoh lesung sering dibunyikan oleh warga Omah Pasinaon selain pada saat gerhana bulan, juga dilakukan 
pada saat ada festival kesenian tradisional, bersih desa, atau lombalomba desa. Ciri khas dari kesenian ini adalah alu dan lesungnya. Alu adalah alat yang terbuat dari kayu untuk menumbuk, sedangkan lesung (berbentuk mirip perahu) digunakan untuk memisahkan padi dari tangkainya. Biasanya alu ini akan ditabuh oleh tujuh hingga delapan orang. Agar lebih menarik, tradisi ini sudah dipadu dengan nyanyiannyanyian Jawa, dan alunan suara dapat dipadukan dengan nada musik campur sari tradisional.

Kesenianini diharapkan mampumemberdayakan perempuan terutama ibu rumah tangga yang tidak bekerja dan anak-anak perempuan, karena seluruh pemainnya perempuan dan memiliki daya tarik tersendiri bagi wisatawan.

4) Wayang Beber Gelaran II

Di Dusun Gelaran II terdapat khazanah budaya yang teramat langka yakni Wayang Beber tertua peninggalan jaman kerajaan Majapahit, yang saat ini sudah keturunan yang ke 15 dari pemilik pertama, yakni Mbah Remeng Mangunjaya. Di seluruh dunia artefak Wayang Beber tinggal tersisa dua, satunya di Gelaran dan satunya lagi di Pacitan. Kesenian ini diharapkan mampu memberdayakan perempuan terutama ibu rumah tangga yang tidak bekerja dan anakanak perempuan, karena seluruh pemainnya perempuan dan memiliki daya tarik tersendiri bagi wisatawan.

5) Seni Karawitan

Dari wawancara dengan Ibu Sy sebagai anggota masyarakat yang aktif mengikuti aktivitas di Kelompok Karawitan "Sarwo Laras" di Desa Bejiharjo didapat jawaban mengenai potensi dan masalah perempuan. Potensi masyarakat yang diungkapkan oleh Ibu Sy adalah adanya program
Raskin dan kompor gas dari pemerintah. Dari program itu Ibu Sy merasa terbantu untuk mengurangi beban dalam mencari kayu bakar. Selain itu beliau menuturkan bahwa potensi alam seperti kedelai juga menjadi potensi yang baik untuk dikembangkan. Selama ini kedelai hanya dibuat menjadi tahu dan belum ada kreasi lain. Ibu Sy juga menuturkan bahwa tidak ada permasalahan yang dialami kaum perempuan dalam aktivitas mereka untuk memperoleh layanan dari pemerintah desa seperti lembaga pendidikan dan pelatihan. Namun, masih banyak kendala di bidang transportasi dan lembaga ekonomi masyarakat. Transportasi umum belum bisa diakses masyarakat Desa Bejiharjo dan lembaga perkreditan modal juga belum ada. Yang ada hanyalah bank harian yang mematok bunga pinjaman yang sangat tinggi.

\section{b. Sumber daya alam}

Desa Bejiharjo memiliki sumber daya alam yang sangat potensial untuk dikembangkan dalam upaya meningkatkan pendapat dan kesejahteraan anggota masyarakatnya, antara lain:

\section{1) Goa Pindul}

Goa Pindul adalah salah satu dari goa di daerah Gunungkidul yang dialiri aliran sungai di bawah tanah. Panjang totalnya $300 \mathrm{~m}$ dan lebar rata-ratanya 5-6 m, ke dalam air antara 4-7 $\mathrm{m}$, tinggi permukaan air kelangit-langit goa sekitar 4,5 m, waktu tempuh sekitar 20-40 menit. Aliran air di dalam goa cukup tenang, sehingga tidak diperlukan ketrampilan yang tinggi untuk menyusurinya dan goa ini cocok untuk segala usia. Menurut perkembangan sistem goa, Goa Pindul ini termasuk dalam Goa Stadia Wisata. Goa Pindul terbagi menjadi 3 zona yaitu zona terang, zona remang, zona gelap abadi. Di bagian dalam goa terdapat sebuah 
stalagtit yang sudah menyatu dengan stalagmit sehingga tampak seperti sebuah pilar dengan ukuran lebar lima rentangan tangan orang dewasa. Di tengah goa terdapat ruang yang cukup besar dengan lubang di atasnya sehingga sinar matahari dapat masuk melalui lubang tersebut. Bagian tersebut adalah yang disebut dengan zona terang. Lubang di atas goa ini seringkali digunakan sebagai jalan masuk vertikal oleh anggota tim sar yang hendak melakukan latihan.

Nama Goa Pindul sendiri berasal dari kisah perjalanan Ki Juru Mertani dan Ki Ageng Pemanahan yang diutus oleh Panembatan Senopati di Mataram untuk membunuh bayi lakilaki buah cinta putri Panembahan Senopati yaitu Mangir Wonoboyo dari Mangiran (Bantul). Dalam perjalanannya, kedua abdi itu sepakat untuk tidak membunuh sang bayi. Keduanya lalu pergi ke arah timur (arah Gunungkidul) hingga tiba di suatu dusun di daerah Karangmojo. Di sana keduanya menggelar tikar dan alas tempat tidur bekas persalinan sang bayi yang kemudian menguburnya. Dusun tersebut dinamakan dusun Gelaran. Sementara itu sang bayi terus saja menangis. Kedua utusan itu pun memutuskan untuk memandikan sang bayi. Ki Juru Mertani naik ke salah satu bukit dan menginjak tanah di puncak bukit dengan kesaktiannya, tanah yang diinjak pun runtuh dan mengangalah sebuah lubang besar dengan aliran air di bawahnya. Sang bayi kemudian dibawa turun dan dimandikan di dalam lubang tersebut. Saat dimandikan, pipi sang bayi terbentur (kebendhul) batu yang ada di dalam, karena peristiwa tersebut akhirnya goa itu dinamakan Goa Pindul.

Goa Pindul ini sekarang telah dijadikan objek wisata nasional dan inter- nasional yang dikelola oleh anggota masyarakat setempat. Berdasarkan pengamatan di lapangan bahwa potensi wisata ini sebagian besar masih dikelola oleh laki-laki dan belum banyak melibatkan perempuan, padahal goa ini memiliki potensi yang sangat besar dalam memberdayakan perempuan untuk memperluas lapangan pekerjaan sehingga dapat meningkatan pendapatan, memberikan pelayanan guide, menambah seni pertunjukan di area goa, dan sebagainya. Hadirnyan wisata Goa Pindul membuka peluang usaha bagi ibu-ibu untuk berjualan barang-barang atau bahan makanan.

\section{2) Kali Oya}

Di balik hamparan persawahan di sebelah utara Goa Pindul terdapat sebuah sungai yang eksotis bernama Kali Oyo. Sungai ini tampak sangat indah karena tebing-tebing batu yang unik. Kali Oyo dan Goa Pindul merupakan bagian dari bentang alam kars. Goa Pindul merupakan endokars, sedangkan Kali Oyo merupakan eksokars. Sungai yang melewati Desa Bejiharjo ini mempunyai stadia sungai dewasa, yang dicirikan erosi lateral yang sudah mulai berkembang dan lembah sungai berbentuk $U$.

Batuan yang ada pada Kali Oyo adalah batu gamping yang berasal dari formasi Wonosari dan merupakan batu gamping berlapis yang mempunyai dip/arah kemiringan relatif kearah selatan dengan besar kemiringan relatif kecil. Batu gamping ini mengalami proses peralutan yang disebabkan oleh aliran air pada Kali Oyo dan proses tektonik yang menyebabkan terjadinya rekahan pada litologi batu gamping tersebut. Saat ini sungai ini telah dimanfaatkan sebagai area tube rafting. Di musim penghujan, jalur untuk olahraga ini lebih panjang dari jalur kemarau dengan arah aliran relatif dari utara 
menuju selatan. Kali ini memiliki potensi wisata yang sangat menarik, dan saat ini mulai dimanfaatkan oleh sebagaian masyarakat Bejiharjo salah satu tujuan wisata untuk memperkuat tempat wisata yang lain. Potensi wisata ini juga dapat dikembangkan untuk memberdayakan ibu-ibu rumah tangga yang tidak bekerja ikut terlibat dalam pengelolaan wisata atau menjadi menyediakan layanan makanan atau penyewaan alat-alat wisata.

3) Goa Sie Oyot

Masih ada lagi Goa yang tidak kalah indahnya di Desa beijiharjo, yaitu Goa Sie Oyot, yang masih terletak di dusun Gelaran II. Petualangan $e x-$ treme menyusuri Goa Sie Oyot akan menemukan hamparan (ribuan) stalagtit yang masih aktif dan stalagmit yang sudah menyatu dengan stalagtit, dan juga akan ditemui air terjun di dalam perut bumi ini, tetapi air terjun ini berada di balik dinding perut bumi sehingga belum bisa terlihat. Sementara itu, Crew Wira Wisata Karang Taruna Gelaran II masih berupaya agar bisa dinikmati oleh pengunjung. Goa Sie Oyot saat ini baru digali dan ditemukan untuk menambah potensi goa wisata yang lebih menarik dan sangat potensial dalam memberdayakan perempuan dalam memperluas lapangan pekerjaan dan mengurangi beberapa konflikinternalyang terjadi di masyarakat Bejiharjo.

4) Mata Air Suroh

Mata Air Suroh merupakan sungai bawah tanah yang muncul ke permukaan dan membentuk kolam. Pada kolom ini terdapat ikan-ikan kecil cukup banyak yang bisa difungsikan sebagai terapi ikan secara alami. Mata air ini belum dikelola secara professional dan belum dimanfaatkan secara optimal sebagai objek wisata atau sumber pendapatan yang lain sehingga masih sangat alami dan belum mampu memberikan konstribusi pada kesejahteraan masyarakat secara optimal. Padahal jika dilihat secara ekonomis, mata air ini memiliki potensi yang sangat besar untuk dimanfaatkan untuk wisata, air minum atau terapi kesehatan, sehingga mampu memperluas lapangan pekerjaan dengan memberdayakan anggota masyarakat termasuk kaum ibu rumah tangga yang belum bekerja.

5) Lahan pekarangan

Hasil pertanian di desa ini melimpah di saat musim panen tiba, namun permasalahannya masih terletak pada kreativitas pengolahan kedelai menjadi kreasi masakan lainnya. Sedangkan permasalahan yang dihadapi perempuan dalam mengakses layanan pemerintah desa adalah kegiatan kursus yang kurang variatif dan juga kendala transportasi di desa yang sulit. Ibu Py adalah perempuan yang aktif dalam banyak kegiatan kelompok yakni Kelompok Karawitan, Arisan PKK, dan senam. Ibu Py juga menuturkan bahwa di Desa Bejiharjo terdapat banyak layanan yang memfasilitasi warga untuk simpan pinjam seperti Koperasi PKK Desa, Koperasi Kelompok Tani dengan cara yang mudah. Selain itu beliau menuturkan bahwa potensi alam seperti kedelai juga menjadi potensi yang baik untuk dikembangkan. Selama ini kedelai hanya dibuat menjadi tahu dan belum ada kreasi lain. Ibu Sy juga menuturkan bahwa tidak ada permasalahan yang dialami kaum perempuan dalam aktivitasnya dalam memperoleh layanan dari pemerintah desa seperti lembaga pendidikan dan pelatihan. Namun, masih banyak kendala di bidang transportasi dan lembaga ekonomi masyarakat. Transportasi umum belum bisa diakses masyarakat Desa Bejiharjo dan lembaga perkreditan 
modal juga belum ada, yang ada hanyalah bank harian yang mematok bunga pinjaman yang sangat tinggi.

\section{c. Sumber Daya Manusia}

Desa Bejiharjo merupakan kawasan desa agropolitan Kabupaten Gunungkidul serta desa wisata yang sebagian besar mata pencaharian penduduknya adalah petani. Dilihat dari latar belakang pekerjaan, penduduk Bejiharjo memiliki mata pencarian sebagai berikut: 1) PNS sebanyak 174 orang, 2) Pensiunan PNS: 121 orang, 3) TNI / POLRI: 26 orang, 4) Pedagang: 754 orang, 5) Tukang: 371 orang, 6) Buruh swasta: 1.714 orang, 7) Petani: 4.480 orang, 6) Peternak: 399 orang, dan 7) Lainnya : 2.054 orang. Dilihat dari tingkat Pendidikan yang dimiliki, meliputi; 1) sarjana: 320 orang, Diploma: 78 orang, SMA/SMK: 2868 orang, SMP: 120 orang, SD; 1.159 orang, dan tidak tamat SD: 1.356 orang.

Dari data tersebut, terlihar bahwa sumber daya manusia di Desa Bejiharjo Kecamatan Karangmojo rata-rata telah mengenyam pendidikan, baik SD, SMP, maupun SMA/SMK bahkan ada sebagian yang mengenyam perguruan tinggi. Sumber daya ini dapat dimanfaatkan untuk membantu memberdayakan perempuan terumata ibu-ibu rumah tangga yang tidak bekerja melalu kegiatan diklat keterampilan, diklat kewirausahaan, dan kegiatan kecakapan hidup lainnya. Secara lebih detail hal ini dapat dijelaskan sebagai berikut.

1) Organisasi Ekonomi

Desa Bejiharjo telah memiliki beberapa organisasi ekonomi yang dikelola secara mandiri oleh masyarakat dan pemerintah. Organisasi ekonomi tersebut antara lain: koperasi desa, BKK ranting Kecamatan Karangmojo, BMT, Koperasi karang taruna, koperasi simpan pinjam, KUM (kelompok usaha bersama) dan lainnya. Organisasi ekonomi tersebut dapat dimanfaatkan sebagai media untuk memberdayakan potensi ekonomi masyarakat khususnya ibu rumah tangga yang tidak bekerja. Bentuk layanan yang dapat dikembangkan antara lain; penyediaan modal, pemberian layanan diklat keterampilan, diklat kewirausahaan dan pemberian pendampingan.

2) Organisasi kemasyarakatan

Organisisasi kemasyarakatan yang ada di desa Bejiharjo memiliki potensi yang sangat besar dalam memberdayakan perempuan di desa ini. Adanya peran organisasi kelompok masyarakat seperti darma wanita, kelompok karawitan, kelompok PKK, dan kelompok senam ibu-ibu dapat menjadi wadah atau media pemberdayaan perempuan di segala bidang. Berdasarkan hasil pengamatan, diketahui bahwa berjalannya kegiatan ini berkat dukungan seluruh masyarakat baik pengurus PKK maupun anggota lainnya. Setiap aktivitas yang dilakukan baik arisan, simpan pinjam, dan sosial dilakukan dengan antusias oleh setiap anggota arisan PKK. Namun tidak dapat dipungkiri bahwa keberadaan pengurus sangatlah penting untuk mendampingi jalannya kegiatan agar berjalan tertib dan bermanfaat. Peran pengurus tidak hanya sebagai pendamping kegiatan namun juga sebagai tim kreatif untuk mencari materi tambahan dari nara sumber lain untuk disampaikan dalam kegiatan arisan PKK.

3) Jejaring dan akses sosial

Perkembangan sosial sendiri diartikan sebagai kemampuan berperilaku yang sesuai dengan tuntutan sosial. Sikap seseorang terhadap orang lain dan pengalaman sosial akan tergantung pada pengalaman belajar selama bertahun-tahun awal kehidupan yang merupakan masa penentunan. Perkembangan sosial merupakan perkembangan tingkahlaku anak dalam menyesuaikan diri 
dengan aturan-aturan yang berlaku di masyarakat. Perilaku sosial adalah perilaku yang mencerminkan kemampuan hidup berdampingan dengan sesamanya yang diwujudkan dengan penyesuaian diri dengan lingkungan, menerima perbedaan budaya dan menghargai perbedaan pada anak-anak dan keluarga serta budaya mereka. Maka dalam hal ini perkembangan perilaku sosial yang dimaksud dalam penelitian adalah tingkah laku yang diwujudkan dengan perilaku menghargai orang lain, kepercayaan diri, saling berbagi, kerjasama dan cara pemecahan masalah.

Untuk memecahkan berbagai permasalahan tersebut diperlukan jejaring sosial dalam kehidupannya. Jejaring sosial yang sangat potensial telah dijalin oleh masyarakat Bejiharjo Kecamatan Karangmojo antara lain: a) Perguruan tinggi (UNY, Universitas Atmajaya, UGM, UAD, STIKES), b) Perbankan (BCA, Bukopin, BKK, BPD, BRI, dan beberapa BPR), c) Kelompok masyarakat Bejiharjo diperantauan, d) lembaga pemerintah, beberapa organisasi sosial dan keagamaan lainnya yang telah peduli pada pemberdayaan masyarakat Bejiharjo.

\section{PEMBAHASAN}

Permasalahan yang berkaitan dengan perempuan ibu rumah tangga, sangat variatif dan kompleks yang cenderung menjalankan peran domestik, akan tetapi ada juga yang bermata pencaharian petani dan pengrajin. Mata pencaharian sebagai buruh tani adalah mata pencaharian terbesar masyarakat Indonesia, sedangkan mata pencaharian sebagai pengrajin belum banyak. Di dalam kedua masyarakat ini, terdapat sebuah budaya unik antara lain: 1) ketergantungan yang cukup besar terhadap alam, 2) sikap nrimo terhadap kondisi yang terjadi, dan 3) lambat dalam sentuhan teknologi. Oleh karena itu, perempuan khusunya ibu rumah tangga yang tidak bekerja di perdesaan relatif lambat dalam mengadaptasi sebuah perubahan, terutama perubahan teknologi. Dalam komunitas masyarakat di pedesaan, umumnya yang banyak bekerja adalah kaum perempuan, kecuali untuk tugas-tugas yang membutuhkan tenaga berat, seperti memotong kayu, lebih banyak dilakukan oleh kaum laki-laki. Namun, di Bejiharjo yang lebih banyak bekerja adalah kaum laki-lakinya. Banyak perempuan terutama ibu rumah tangga yang tidak bekerja. Mereka lebih bertanggung jawab mengurus rumah tangga dan secara ekonomi tergantung pada suami. Pemberdayaan perempuan diperlukan dalam upaya meningkatkan kemampuannya, sehingga dapat menciptakan kehidupan yang lebih baik.

Dari uraian di atas terlihat bahwa sebenarnya perempuan tidak lebih dari pengurus rumah yang selalu menjadi nomor dua. Perempuan tidak berhak menjadi penentu dalam memutuskan hal-hal yang menyangkut rumah tangganya. Mereka sering kali tidak memiliki kemauan dan keberanian untuk menjadi sejajar dengan suami. Perempuan harusnya memiliki kepekaan dalam menangkap perubahan dan aspirasi yang berkembang di masyarakat. Dalam pandangan Kartini (2001), perempuan harus mampu menggerakkan dan membuat perubahan-perubahan sosial ke arah yang lebih baik atau sebagai agent of social change. Pentingnya pendidikan bagi perempuan tidak hanya sekedar sebagai upaya mensejajarkan perempuan dengan lelaki, namun lebih dari itu yaitu; 1 ) perempuan (ibu) yang terdidik akan mampu membesarkan keluarga yang lebih sehat, 2) perempuan yang terdidik cenderung mempunyai anak yang lebih sedikit, sehingga dapat menahan laju pertumbuhan jumlah penduduk, 3) perempuan terdidik lebih produktif, baik di rumah maupun di tempat kerja 4) perempuan terdidik cenderung membuat keputusan lebih independen dan bertindak untuk dirinya sendiri, dan 5) perempuan terdidik cenderung menolong anak-anaknya untuk menjadi terdidik (Dwi Darmanto, 2010). 
Aspek-aspek pemberdayaan (empowerment) meliputi fisik, intelektual, ekonomi, politik, dan kultural. Dengan demikian, pemberdayaan itu mencakup pengembangan kemanusiaan secara total (total human development). Sementara itu, aspek-aspek partisipatori meliputi: (1) punya kesamaan hak memperoleh akses atas sumberdaya dan pelayanan sosial, (2) menyangkut hak-hak dasar, (3) berkembang dalam kesamaan, (4) menguntungkan, (5) berkenaan dengan hasrat atau pun kebutuhan individual untuk ikut andil bagi kepentingan bersama, (6) memanfaatkan secara optimal namun wajar apa yang telah tercipta di dunia ini, (7) lebih bercorak moral daripada hukum, dan (8) berkaitan erat dengan kebutuhan manusiawi khususnya. Banyak potensi yang dapat dimanfaatkan untuk memberdayakan perempuan terutama ibu-ibu rumah tangga yang tidak bekerja di Bejiharjo, antara lain optimalisasi pemanfaatan sumber daya alam (lahan dan wisata), sumber daya manusia (membantu dalam kegiatan pendidikan dan pelatihan keterampilan kewirausahaan, memperluas akses dan jejaring sosial), karakter budaya (nilai rasa kebersamaan dan kegotongan yang kuat, wisata budaya, wisata religi dan adat), serta jejaring sosial dan modal sosial yang sangat potensial untuk dikembangkan

\section{SIMPULAN}

Berdasarkan hasil penelitian dan pembahasan seperti di atas dapat dikemukakan beberapa kesimpulan sebagai berikut:

1. Permasalahan yang dihadapi oleh perempuan, khususnya ibu rumah tangga yang tidak bekerja, dapat dikelompokan menjadi: 1) permasalahan yang berkaitan dengan kemiskinan (banyak perempuan yang tidak bekerja, sehingga pendapatan keluarga rendah, sementara kebutuhan hidup terus meningkat, adanya pola pikir "nrimo ing pandum", tidak dimilikinya keterampilan, terbatasnya kesempatan kerja, sedikitnya sumber pendapatan; 2) permasalahan yang berkaitan dengan sosial budaya (masih kuatnya nilai yang dianut, bahwa perempuan sebagai "konco wingking" atau nomor dua dalam keluarga); 3) permasalahan yang berkaitan dengan kekerasan rumah tangga (adanya sebagian suami yang menelantarkan keluarga, angka perceraian tinggi); 4) permasalahan yang berkaitan dengan pendidikan dan latihan (keterampilan perempuan rendah), akses untuk memperoleh keterampilan dan pendidikan sangat terbatas; dan 5) permasalahan yang berkaitan dengan adat istiadat (masih banyaknya upacara adat yang sering menambah beban ekonomi kehidupan masyarakat, adanya pandangan perempuan sebagai pihak nomer dua yang bertugas mengurus rumah tangga).

2. Banyak potensi yang dapat dimanfaatkan untuk memberdayakan perempuan terutama ibu-ibu rumah tangga yang tidak bekerja di Bejiharjo, antara lain: optimalisasi pemanfaatan sumber daya alam (lahan dan wisata), sumber daya manusia (membantu dalam kegiatan pendidikan dan pelatihan keterampilan kewirausahaan, memperluas akses dan jejaring sosial), karakter budaya (nilai rasa kebersamaan dan kegotongan yang kuat, wisata budaya, wisata religi dan adat), jejaring sosial dan modal sosial yang sangat potensial untuk dikembangkan.

\section{DAFTAR PUSTAKA}

Burr, dkk. 1977. “An Emperical Test of Rodman"s Theory of Reseources in Culture Conter". Journal of marriage And Family

Biro Pusat Statistik. 2008. Profil Kemiskinan di Indonesia Maret 2008. Jakarta, N0. 37/07/Th. XI, 1 Juli 2008.

Dwi Darmanto. 2010. Model Pemberdayaan Perempuan Melalui Kejar KF. Surabaya: BPPLSP Regional VI Surabaya

Farida Hanum, 2007. Diktat Sosiologi Gender. Yogyakarta: FIP UNY

Kartini Kartono, 2001. Patologi sosial. Jakarta: Raja Grafindo Persada 